\title{
New readings from Oinoanda (SEG 44, 1200), Olbasa (SEG 48, 1536) and Maionia
}

\author{
Nicholas P. MILNER*
}

\section{Aurelius Aisim[os] pleistonikes ${ }^{1}$}

The late Alan Hall and Nicholas Milner (Hall - Milner 1994, 42 no. 36 = SEG 44, 1994, 1200) published an inscribed, fragmentary statue-base that had been re-used in (a presumed repair to) a wall in an Imperial peristyle building immediately west of the Agora at Oinoanda, a GraecoRoman city site in northern Lycia (fig.1). ${ }^{2}$

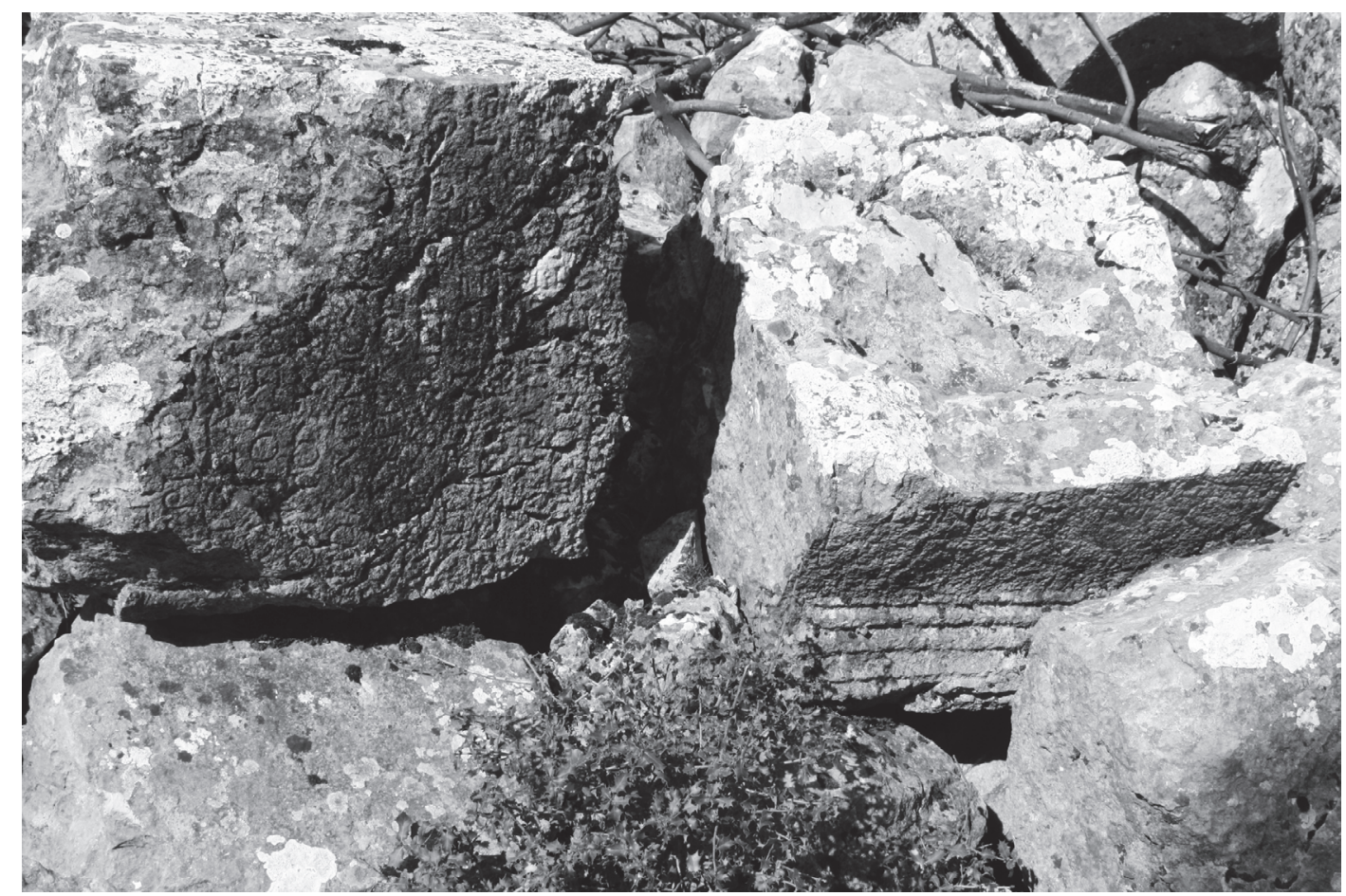

Fig. 1) Photo N. P. Milner.

* Dr. Nicholas P. Milner, Honorary Research Associate, Department of History, University College London (nicholas.milner@ucl.ac.uk; https://orcid.org/0000-0002-4804-4710). I thank the anonymous reviewers for their suggestions and help with this article.

${ }^{1}$ I am grateful to the late Martin Bachmann, deputy director, Deutsches Archäologisches Institut (Abteilung Istanbul), for inviting me to take part in the survey work at Oinoanda, and the Turkish Government representatives, Bay Mustafa Barış Harmankaya, of the General Directorate of Cultural Heritage and Museums, Istanbul, and Bayan Nilgün Şentürk, of the Museum of Anatolian Civilisations, Ankara, for their assistance at the seasons concerned.

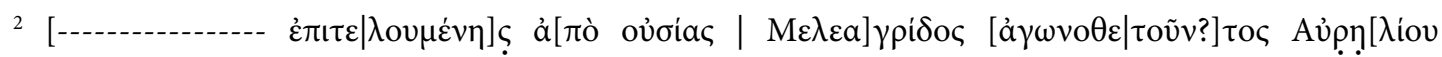

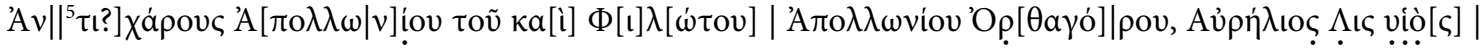

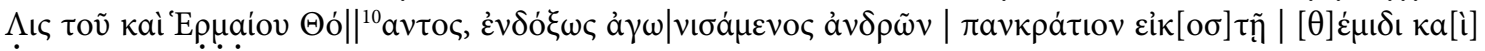

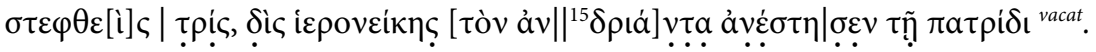


The last two lines (14-15) are on a separate fragment in the wall beside the main fragment, immediately to the right of it. I was able to study the fragments in situ in 2011-12, and after reconsideration of the evidence further study has led to the amendments here proposed.

There are two unclear passages in the text, at lines 8-9 and in line 14. In the original publication, the reading of lines 8-9-pov, A $\dot{v}$ -

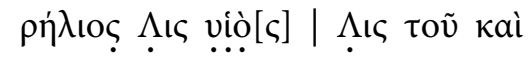
Epuaiov @ó- involved the name

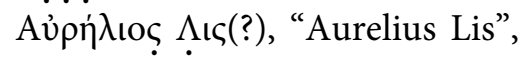
where it was suggested that the cognomen "Lis" was related to the final element in other epichoric Lycian names such as Moaleis, Toalis, and which coincided with $\lambda i s$, an epic word for a lion. However, such a name for a man has continued to be unparalleled despite the rather extensive evidence of the Lycian onomasticon, and it now appears unconvincing. If it is not a complete name, therefore, one must extend the reading to the subsequent letters, whilst if necessary revising

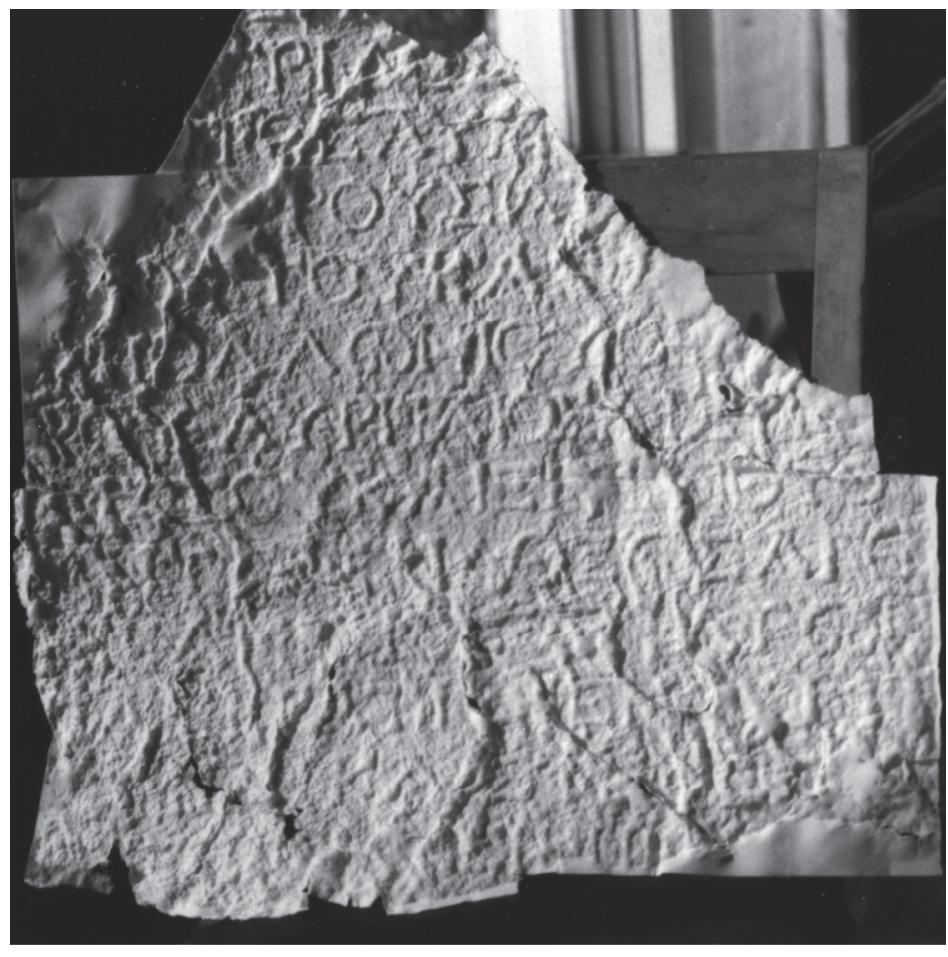

Fig. 2) Photo Alan Hall, lines 3-14, reprinted from Hall - Milner 1994, Plate 2.10.1 (c)British Institute at Ankara. the reading of the doubtful first letter $\Lambda$, in the light of a much improved resource for the Greek onomasticon, thanks to the Oxford Lexicon of Greek Personal Names (LGPN) (fig. 2, 3).

It immediately becomes clear that upsilon is not the most likely letter after $\Lambda \mathrm{I} \Sigma$-. This fourth letter certainly has a vertical hasta in its lower part (destroyed above), and we can start by considering eta, iota, kappa, pi, tau, as well as upsilon. We can see from LGPN vols I-Vc that upsilon produces no plausible name after $\Lambda \mathrm{I} \Sigma$-, and neither does pi or tau. If it were part of a letter having two upright hastae, there is no sign of the crossbar of an eta, where the surface appears intact. Further, no plausible Greek name is known to start $\Lambda ı \sigma \mathrm{l}-$, or indeed $\Delta \mathrm{l \sigma l-}$, and $\Delta$ i $\sigma \kappa o \zeta$ is ruled out by the lack of visible arms for the kappa, where the surface appears intact. $\Delta$ iovpos, on the other hand, is vanishingly rare, with only one example in LGPN vols I-Vc. Then, if $\Lambda \mathrm{I} \Sigma$ - were AI $\Sigma$-, plus up-

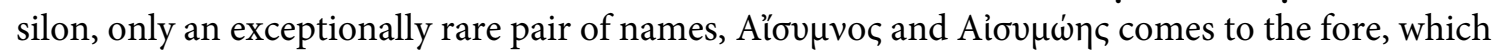
for lack of space left in line 8 (there is room only for another 2-3 letters) cannot be considered here. On a balance of probabilities, therefore, iota is more likely than any other letter, so that $e x$ hypothesi iota will be a continuation of a name beginning with $\mathrm{AI} \Sigma$-.

Then, as line 9 starts with a new name being a patronymic in the genitive case, the previous name in Airt- must end at the right edge of line 8, so that a maximum of only seven letters is available

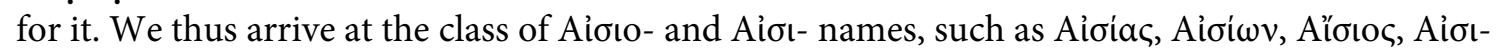




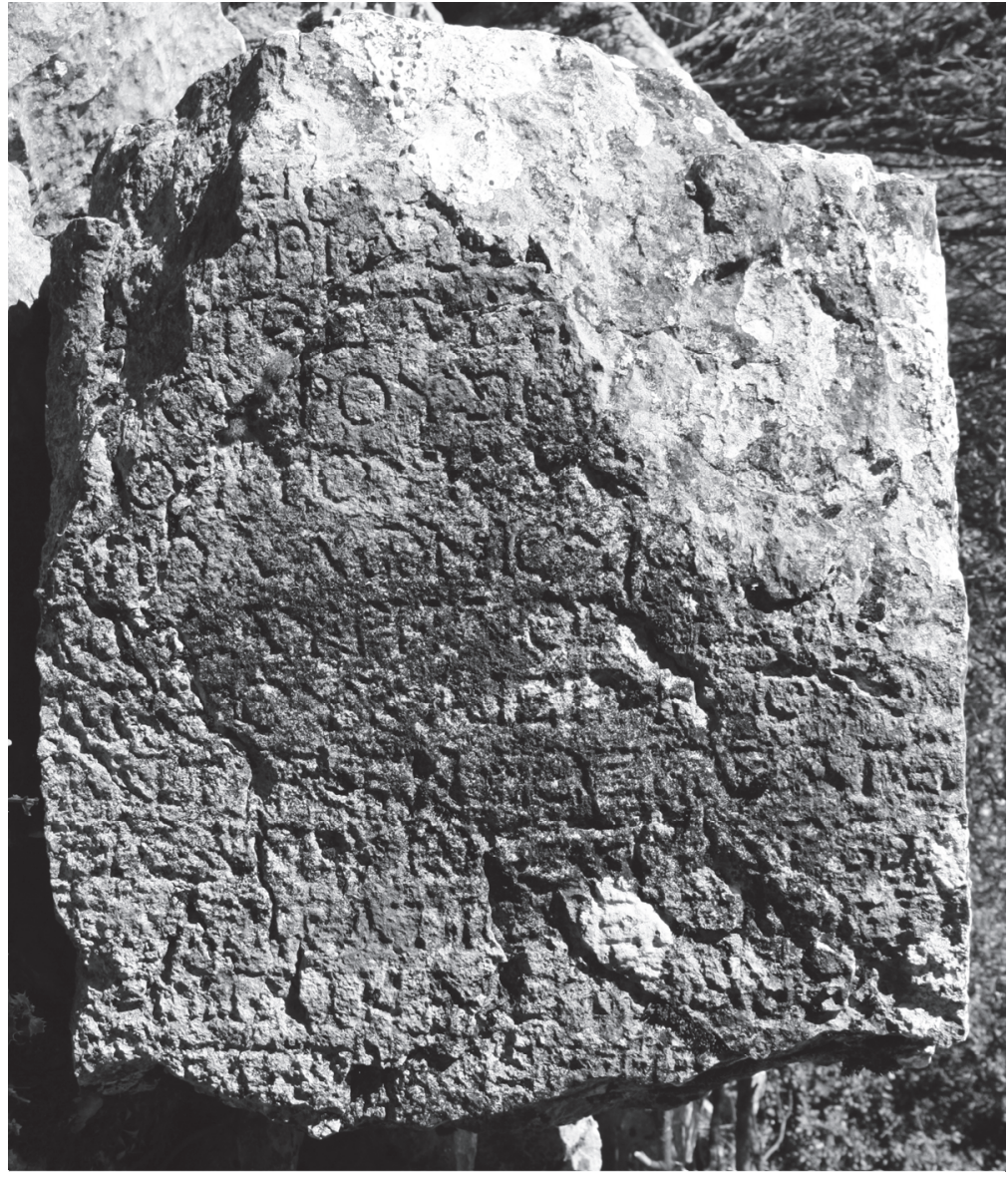

Fig. 3) Photo N. P. Milner, lines 3-14.

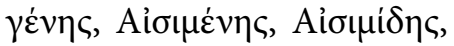
all referring in one way or another to Aĩoa, Fate. After Airl- the evidence of the fifth letter also beginning with a vertical hasta would point to one of the three compound names listed above, but they are too long. The vertical hasta after iota could belong to several different letters, but the combination of the previous letters points to mu. It should be added that the sixth letter should not be read with the editio princeps as a possible omicron; examination of the stone suggests that what appears in the squeezes is in fact damage at the break, where the original surface of the stone is missing, and hence this letter should be treated as wholly in a lacuna.

The proposed solution to the observed traces is Ail $\sigma ! \mu[o \zeta]$, meaning "appointed by fate", a name from an intersecting set with the above group which arose particularly in the Hellenistic period, of names taken directly from an epithet naming a moral quality (see Bechtel 1917, 29, 502). Aisimos has the advantage of being substantially commoner than the older Airt- names, with 26 examples in LGPN I-Vc including 9-10 examples from Mysia or Troas (LGPN Va), as compared

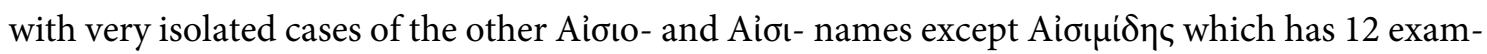
ples in LGPN I-Vc. Yet Aisimos is a relatively rare name, with no previously recorded example from Lycia.

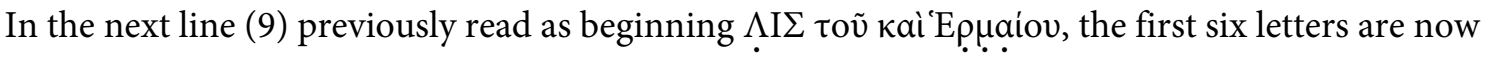
read as APATOY. The second letter previously read as I is now seen to have a loop at the top right, and so will be a rho. At the third letter the loop of the preceding rho and extended left horizontal hasta of the following tau were previously misread as together forming the top bar of (four-barred) sigma, where the letter can now be read as alpha. Thus, the line can be seen to start with A. $<\tau o \tilde{v}>$ kaì Eppaqiov with a haplography of TOY. Aratos, meaning "prayed for," by contrast with Aisimos, is reasonably common across the Greek world with 71 examples in LGPN I-Vc, including one from neighbouring Tlos (TAM 2.2.608, Imperial).

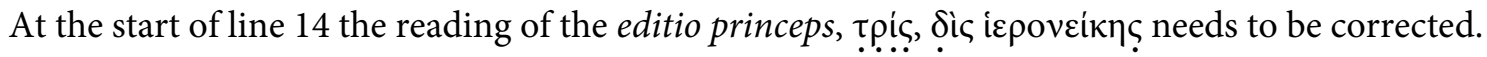
For this reading one would have to accept that several letters were crowded together, which is 
contrary to the mason's expansive style in this inscription, where he spaced them out elegantly (fig. 3, 4, 5). The last line (line 16) is approximately centred (fig. 5).

Furthermore, $\tau \rho i$ i is problematic as syntactically it goes with $\sigma \tau \varepsilon \varphi \theta \varepsilon[i] \varsigma$, "crowned", at the end of the previous line; yet $\sigma \tau \varepsilon \varphi \theta \varepsilon[i] \varsigma$ was one of the terms used to indicate the athletic victory that was being commemorated by the statue on the base. The victory in this case was in the men's pankration; the honorand could not be "three times crowned" for this one event, and to translate it "crowned for the third time" seems inapplicable to a many-times winner such as this honorand, whether a hieronikes or a pleistonikes (on which, see below).

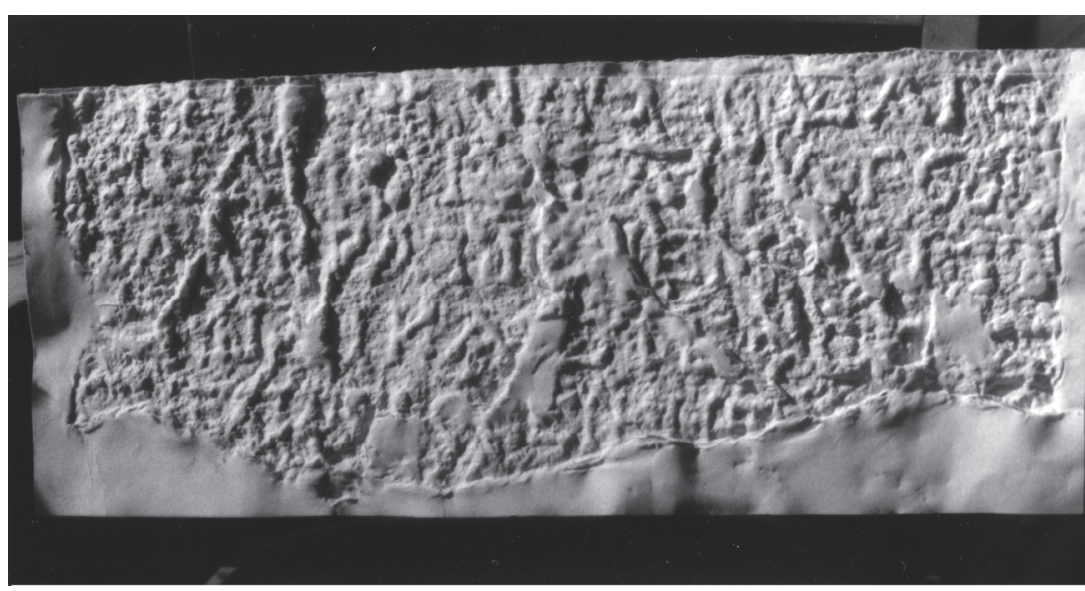

Fig. 4) photo Alan Hall, lines 10-14, reprinted from Hall - Milner 1994, Plate 2.10.3, cBritish Institute at Ankara.
What was read from the squeeze as TPI are the abraded parts of letters immediately above a break in the block, where pi plus an unidentified letter $(\Pi$.$) is$ an equally plausible rationalisation of the traces. What was previously thought to belong to "iota" is the lower, vertical, part of a meandering, mainly diagonal

crack in the stone, running down from line 12; this area occupies the space of illegible lambda. Then comes $\sum$ which is now read as E, and what was read from the squeeze as $\Delta$ is now seen to be a hole in the surface at another diagonal crack rising from left to right. The following iota is confirmed, placed to the right of the crack. Then, contrary to the mason's usual practice, the letters read $\Sigma \mathrm{I}$ in the editio princeps are seen to occupy the space of one square letter, where there is another broad roughly vertical vein and crack in the surface. The "iota" is now explained as merely part of the crack, and the horizontal arms of the sigma (traces of whose pointed angles are visible on the left), which are now eroded away must have continued over this space, if it was a normalsized sigma.

The following curved trace previously read as the letter epsilon would have meant a lunate letterform, contrary to the style used in the rest of the inscription. No middle crossbar is visible. The following letter is now read as a probable tau, not rho, as what was read as its "loop" is not completed down to the vertical hasta in the squeezes. It appears, then, that the lunate letterform, which runs into the left top hasta of the tau, is a curved piece of damage to the surface, which could have been induced by the erosion into one another of apices at the left end of tau and the two horizontal right ends of a four-bar sigma.

The amended reading $\Pi[\Lambda] \mathrm{EI} \Sigma \mathrm{T}$ - results in a reduction of 10 crowded letters to 6 elegantly spaced ones, which accords better with the ductus litterarum of the other lines, so that line 14 now has 18

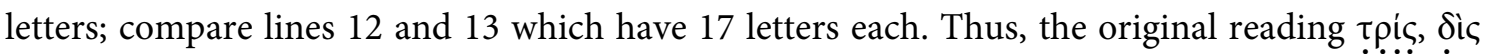

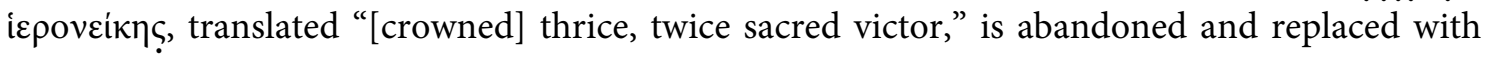




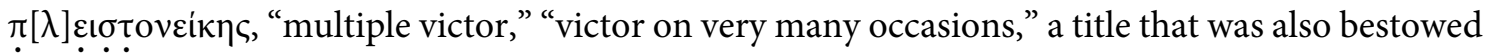
on another Oinoandan pancratiast, L. Septimius Flavianus Flavillianus (SEG 44, 1169).

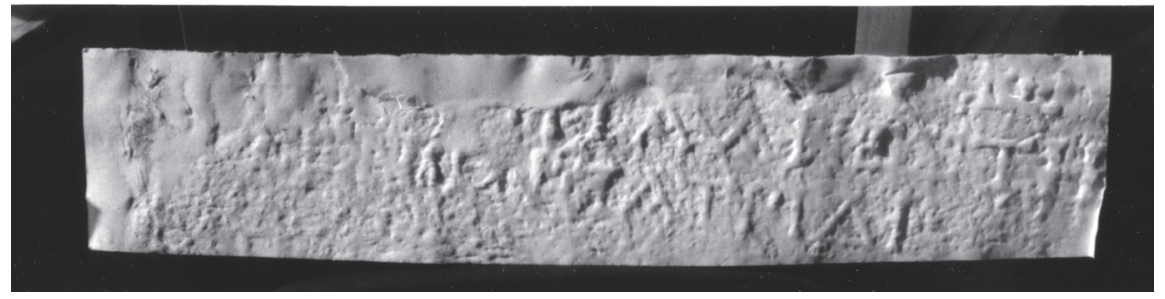

Fig. 5) Photo Alan Hall, lines 15-16, reprinted from Hall - Milner 1994, Plate 2.10.4, @British Institute at Ankara.

The corrected text reads then as follows:

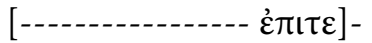

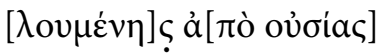

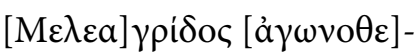

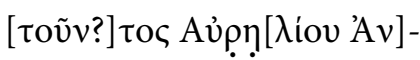

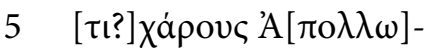

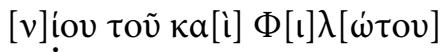

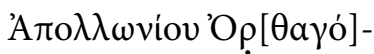

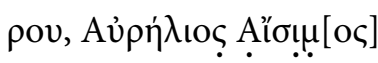

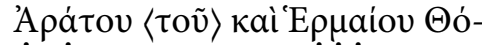

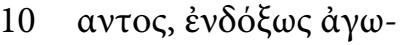

$v ı \sigma \alpha \dot{\mu} \mu \varepsilon v o \varsigma \grave{\alpha} v \delta \rho \tilde{\omega} v$

$\pi \alpha v \kappa \rho a ́ \tau ı v ~ \varepsilon i ̉ \kappa[o \sigma] \tau \tilde{~}$

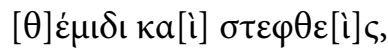

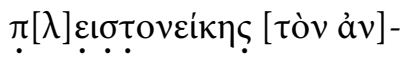

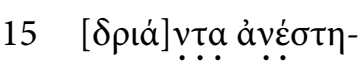

$v v \sigma \varepsilon v \tau \underline{̣} \pi \alpha \tau \rho i \delta \iota^{v a c a t}$

Translation: "When Aurelius Antichares, son of Apollonios alias Philotas, son of Apollonios, son of Orthagoras, was agonothetes of the ... celebrated from the fund of Meleagris, Aurelius Ai$\operatorname{sim}[\mathrm{os}]$, son of Aratos alias Hermaios, son of Thoas, having taken part with distinction in the men's pankration in the twentieth themis and having been crowned (winner), multiple victor, set up the statue for the city."

If the amendments proposed above are accepted, the statue on this inscribed base was that of Aurelius Aisim[os], a local pancratiast of highly respected status as a pleistonikes, "multiple victor," a title which was bestowed on athletes who had won numerous victories. On the evidence of this single base, however, and unlike L. Septimius Flavianus Flavillianus (SEG 44, 1195-1196), he was not a hieronikes - "victor in Sacred games," that is, crowned at an international crown-games which enjoyed the title hieros, "sacred", on which see further Remijsen 2015, 120, 209-10, 242; Robert 1970, 9-10. Contrast too a victor who boasted success in the Olympic games in Elis among

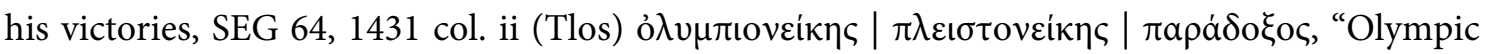
victor, multiple victor, brilliant (victor)"; see further Robert 1957, 229-231.

Date: ca. A.D. 225-264 (Hall - Milner 1994, 42-43).

\section{Manius Petronius Protes ${ }^{3}$}

In Milner 1998, 64 no. 142 = SEG 48, 1998, 1536 I published an inscribed altar to the Sebastoi found by Alan Hall in 1985 at Belenli, which is the site of the Graeco-Roman city, Olbasa. The

\footnotetext{
${ }^{3}$ I am grateful to Prof. Thomas Corsten for discussion of this inscription. I would no longer accentuate

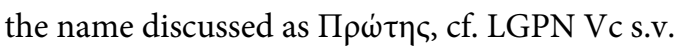


brief text had been imperfectly erased, so that one could still read the letters recording the dedication by a Roman citizen of Greek descent, with tria nomina of which the first two names are Latin men's names, followed by a Greek cognomen (fig. 5). ${ }^{4}$

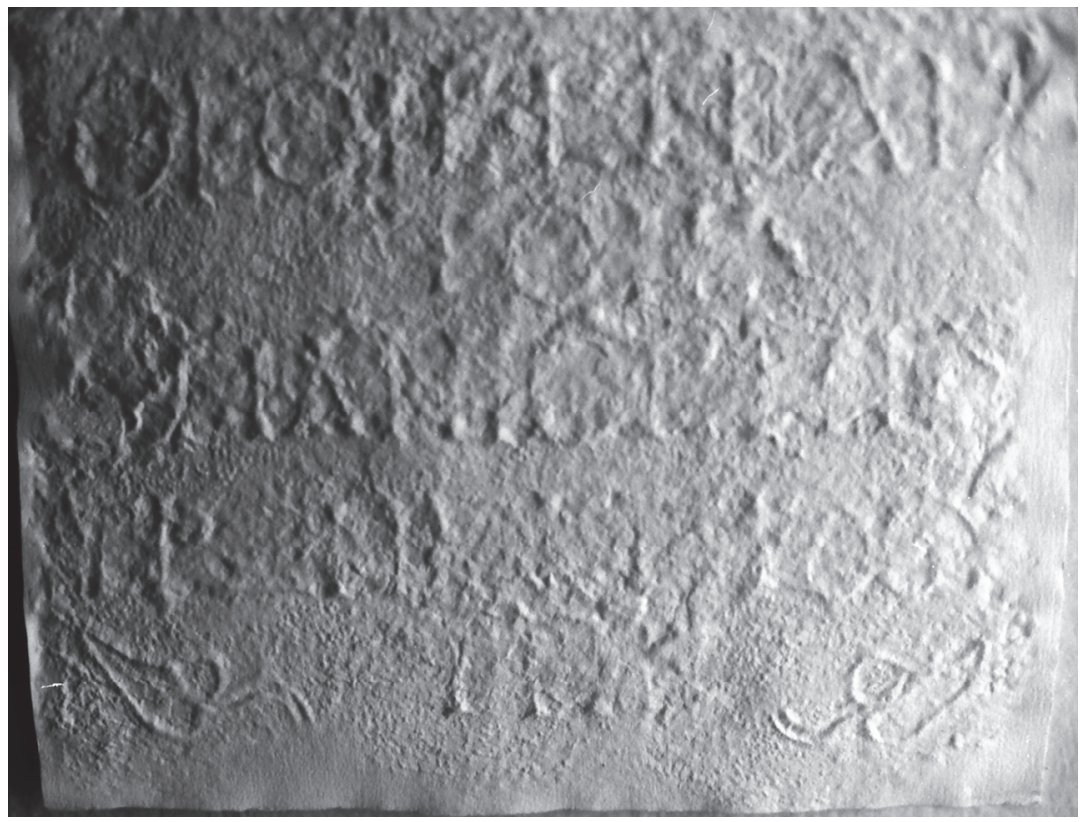

Fig. 6) Photo Alan Hall, "PH15290", Digital Collections and Archives, (C)British Institute at Ankara. Accessed 28.08.2019.
In lines 4-5 the cogno-

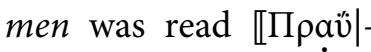
$\tau \eta \varsigma \rrbracket$. This being a feminine abstract noun meaning "gentleness" always seemed unlikely for a male, and further study has convinced me that this is a misreading of the squeeze, where av should be corrected to $\omega$, thus $\llbracket \Pi \rho \omega \mid \tau \tilde{\eta} \varsigma \rrbracket$. The trace of omega is visible, as an arcuated letter form with two large inturned volutes. $\Pi \rho \omega \tau \tilde{\eta} \varsigma$, according to LGPN I-Vc attested 10 times in to-

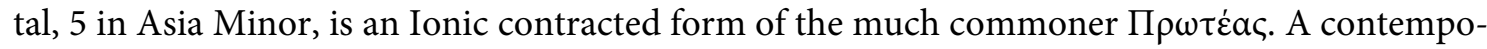
rary example of Proteas comes from nearby Yeşilova (Horsley 2007, 88 no. 119, 2nd-3rd cent. A.D.). Protes/Proteas is derived from the group of names denoting "prince" or "first", including

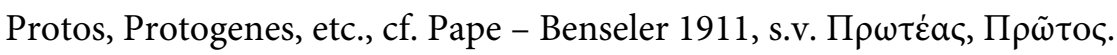

The corrected text reads then as follows:

$$
\begin{aligned}
& \llbracket \Theta \varepsilon o i ̂ \varsigma ~ \sum \varepsilon \beta a \sigma \rrbracket-
\end{aligned}
$$

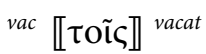

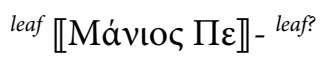

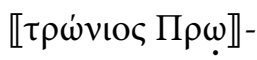

$$
\begin{aligned}
& 5 \text { leaf } \llbracket \tau \tilde{\eta} \varsigma \rrbracket^{\text {leaf }}
\end{aligned}
$$

Translation: "To the theoi Sebastoi (deified Augusti), Manius Petronius Protes (dedicated it)."

\section{Curing a broken leg in Maionia ${ }^{5}$}

Malay - Petzl 2017, 79 no. 44, a confession relief-stele dedicated to Artemis Anaeitis and Meis Tiamou records a cure for one Aur. Tatianos son of Rhesonianos, who was "smitten in the leg",

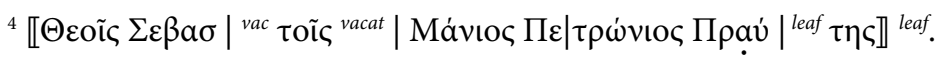

${ }^{5}$ I am grateful to Prof. Petzl for earlier discussion and assistance with this inscription.
} 
where informed by the associated reliefs of a leg with the foot, I translate $\pi$ ó $\delta a$ "leg" rather than "foot" (cf. LSJ s.v. זoúc for this possibility). ${ }^{6}$

Two passages in this text are unclear. The second crux in lines 3-4 reads $\pi \lambda \eta \gamma \varepsilon \dot{~ c}$ กó $\delta \alpha$

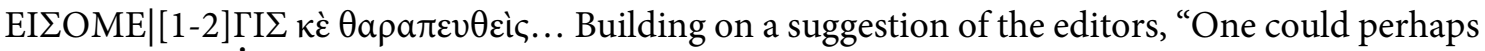
consider $[\dot{\alpha}] \gamma^{\prime} \zeta$, or $\dot{\varepsilon} \mid[\alpha] \gamma^{i} \varsigma$, broken, from ä $\gamma v v \mu$. We would still be left with the unexplained let-

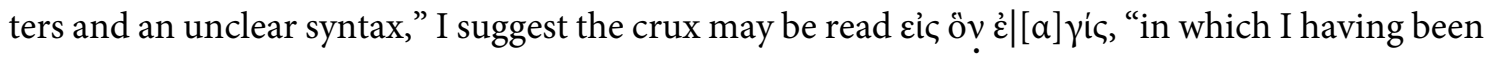
broken," where the gamma seems clear in the photograph. The photograph also shows that the nu of ôv can be read as corrected by the mason from a mu. A parallel for the syntax eis ôv $\dot{\varepsilon} \mid[\alpha] \gamma$ ic

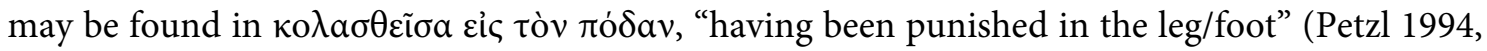

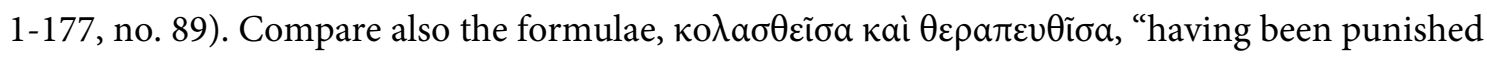

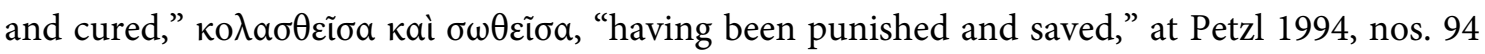
and 114, which support a reading $\dot{\varepsilon} \mid[\alpha]$ yis $\kappa \grave{\varepsilon} \theta \alpha \rho a \pi \varepsilon v \theta \varepsilon i \varsigma$, "having been broken and cured," as a pair of co-ordinate aorist participles passive. The phonetic spelling of the ending of $\dot{\varepsilon} \mid[\alpha]$ yic for

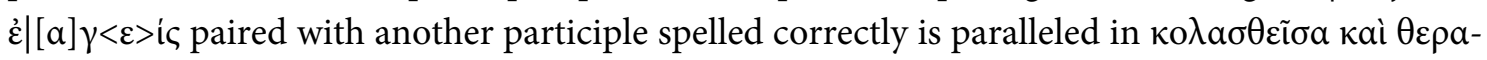
$\pi \varepsilon v \theta \tilde{i} \sigma \alpha$ at no. 94 .

Then, if we read the first crux of line 3 [.] $\Xi O M H N$ with Malay's proposed [ $\dot{\varepsilon}] \zeta$ ó $\mu \eta v$, "I was sitting," the whole confession text makes quite consistent sense with minimal editorial intervention:

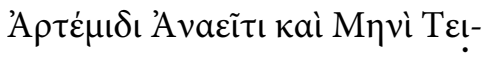

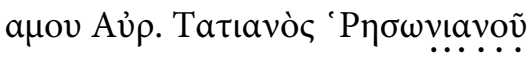

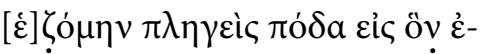

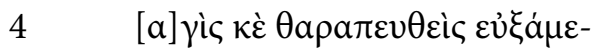

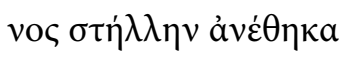

"I, Aurelius Tatianos, son of Rhesonianos, was sitting down after having been smitten in my leg; in which I having had a break and having been cured, put up the stele -having made a vow- to Artemis Anaeitis and Meis Teiamou."

The significance of his sitting down is that he was unable to walk before his cure. There seems little reason to conclude that he suffered two broken legs from the fact that the relief shows that the dedicant put up two colossal images of a leg. A double votive was more valuable than a single.

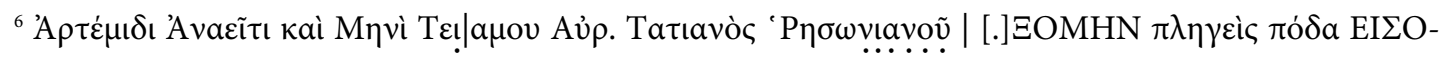
ME|[1-2]
} 


\section{Bibliography}

Bechtel 1917

Hall - Milner 1994

Horsley 2007

LGPN

LSJ

Malay - Petzl 2017

Milner 1998

Pape - Benseler 1911

Petzl 1994

Remijsen 2015

Robert 1957

Robert 1970

Robert, OMS I

Robert, OMS V
A. Bechtel, Die historischen Personennamen des Griechischen bis zur Kaiserzeit, Halle 1917.

A. Hall - N. P. Milner, Education and athletics. Documents illustrating the festivals of Oinoanda, in: D. French (ed.), Studies in the History and Topography of Lycia and Pisidia in Memoriam A. S. Hall (British Institute at Ankara Monograph 19), London 1994, 7-47.

G. H. R. Horsley, The Greek and Latin Inscriptions in the Burdur Archaeological Museum (British Institute at Ankara Monograph 34), London 2007.

P. M. Fraser et al. (edd.), A Lexicon of Greek Personal Names, Oxford, vols. I-, 1987- .

H. G. Liddell - R. Scott - H. S. Jones (edd.), A Greek-English Lexicon, 9th edition, Oxford 1940.

H. Malay - G. Petzl, New Religious Texts from Lydia, Österreichische Akademie der Wissenschaften (Denkschriften der philosophisch-historische Klasse, Band 497), Vienna 2017.

N. P. Milner, An Epigraphical Survey in the Kibyra-Olbasa Region Conducted by A. S. Hall (British Institute at Ankara Monograph 24), London 1998.

W. Pape - G. E. Benseler, Wörterbuch der griechischen Eigennamen, Braunschweig 1911.

G. Petzl, Die Beichtinschriften Westkleinasiens, EpigrAnat 22, 1994, 1-177.

S. Remijsen, The End of Greek Athletics in Late Antiquity, Cambridge 2015.

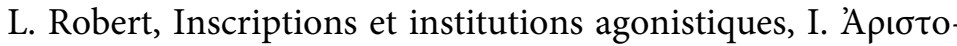
víkпৎ II. Fêtes et magistrats de Tralles, Symbolae Raphaeli Taubenschlag dedicatae II, Eos 48, 1957, 229-238 = OMS I, 644653.

L. Robert, Deux concours grecs à Rome, CRAI 6, 1970, 6-27 = OMS V, 647-658.

L. Robert, Opera Minora Selecta. Épigraphie et antiquités grecques, Tome I, Amsterdam 1969.

L. Robert, Opera Minora Selecta. Épigraphie et antiquités grecques, Tome V, Amsterdam 1989. 


\section{Oinoanda (SEG 44, 1200), Olbasa (SEG 48, 1536) ve Maionia'dan Yeni Okumalar}

Öz

Bu makalede antik Oinoanda (no. 1), Olbasa (no. 2), ve Maionia (no. 3) kentlerinden üç adet yayımlanmış yazıt için düzeltmeler önerilmektedir. 1 numaralı yazıtta zafer kazanmış bir atletin adı ve baba adları Thoas oğlu Hermaios olarak da bilinen Aratos'un oğlu Aurelius Aisimos olarak önerilmiş ve hieronikes, ("kutsal galip") yerine pleistonikes ("çok kere galip") olarak övülmüştür. 2 numaralı yazıtta Sebastoi için adanan yazıtlı bir altarı adayan kişinin cognomeni Protes olarak yeniden okunmuştur. Son olarak, kırık bacağ 1 için şifa bulan birinin kefaret steli olan 3 numaralı yazıtta metnin cümle yapısı düzenlenmiş ve bir harfin değiştirilmesiyle metin netliğe kavuşturulmuştur.

Anahtar Sözcükler: Oinoanda, Olbasa, Maionia, atlet yazıtı, Sebastoi, ex-voto (adak yazıtı), Artemis Anaeitis, Meis Teiamou.

\section{New readings from Oinoanda (SEG 44, 1200), Olbasa (SEG 48, 1536), and Maionia}

\section{Abstract}

This article offers corrections to three published inscriptions, from ancient Oinoanda (no. 1), Olbasa (no. 2), and Maionia (no. 3). In no. 1, the name and patronymics of an athletic victor are proposed to be Aurelius Aisimos, son of Aratos alias Hermaios, son of Thoas, and he is acclaimed with the title pleistonikes, "multiple victor" rather than hieronikes, "sacred victor". In no. 2, the cognomen of the dedicant of an inscribed altar for the Sebastoi is re-read as Protes. Finally, in no. 3 , a confession stele for a man cured of a broken leg, the syntax of the text is restored and elucidated by the emendation of a single letter.

Keywords: Oinoanda, Olbasa, Maionia, athletic inscription, Sebastoi, ex-voto, Artemis Anaeitis, Meis Teiamou. 